Vol. XVIII No. 4

\title{
A Migratory Congregation of Swainson's Hawks
}

\section{by Ralph D. Carson, S.M.N.H., Regina}

On September 16, 1960, Mrs. E. Cruickshank, Mrs. I. G. Smith and I drove out to the farm of $\mathrm{Mr}$. and Mrs. J. H. Horn, seven miles southwest of Regina to investigate a repont of a large flock of hawks which had gathered in their field during the past two weeks. As we drove through a large shelter grove of trees on the Horn farm we were astonished to seie about one hundred Swainson's Hawks (Buteo swainsoni) fly out of the itrees and begin to circle around us. There were many more hawks walking or standing on the ground in an adjacent green summerfallow field around a marsh. These birds appeared to be feeding on insects, possibly crickets, which were extremely abundant. Most of the hawks were in sub-adult plumage, but there were in addition many immatures, several adults, and three or four birds were melanistic or in dark phase plumage. In the same grove of trees were many small birds such as Tree Sparrows, Myrtle Warblers and Flickers.

A wieek later Dr. $R$. Nero and I drove out to make a further check of this unusual gathering but we were disappointed to learn that the birds had deparited several days previously. At this time about a dozen hawk pellets were collected from under the trees. Nearly all of the pellets consisted of solid masses of remains of crickets, but two were composed of grasshopper remainis and one contained pants of a small bird.

Arthur C. Bent states (1937. Life Histories of North American Birds of Prey, Part I, p. 232-233): "Fall.Late in August Swainson's hawks gather into large flocks, wheeling and circling high into the air as they gradually drift southward. . . . Many observers have noted the spectacular fall flights of these hawks, constantly passing in small bands, or in flocks of hundreds." There are apparently few records of this phenomenon in Saskatchewan. Fred W. Lahrman, who has lived on the prairies all his life, was unable to recall ever seeing so large a concentration of Swainson's Hawks. I would be interested in hearing from readers who may have seen this flocking behaviour.

\section{Confiding Young Red Crossbills \\ by Joyce Gunn, Spirit Lake}

This summer we had two visits by Red Crossbills to our yard. On August 10 and 11 we had four birds -one male and three females. They were seen in the spruce trees feeding among the top branches. Their crossed bills and absence of wing bars together with the red colouring of the male, made us certain that we had had our first visit from Red Crossbills.

On October 1 and 2 we were treated to a sample of the tameness of birds. During September, a Red Squirrel had stripped most of the cones from the trees, and cones were everywhere around the yard and doorstep. dropped as the squirrel carried them off to stockpile them in the woodpile. We first noticed the Red Crossbills from the kitchen window as two young birds sat on the ground near the doorstep eating seeds from these dropped cones. I went outside expecting them to fly up, but they didn't, even when I stood right beside them! I finally bent down and gently touched one. Then they both flew up into the spruce, but within moments were back again. During that day I touched the young ones twice more without greatly alarming them. There were two young birds, both orange-red, with no wingbars, and backs that showed all shades of green and purple in the sunlight. There was also a female in the trees, but I did not see her on the ground. The two young spent most of their time feeding from the fallen cones and were tamer than any other birds we have had around. They had no fear of humans or even of our cat which we had to keep in during their stay. 